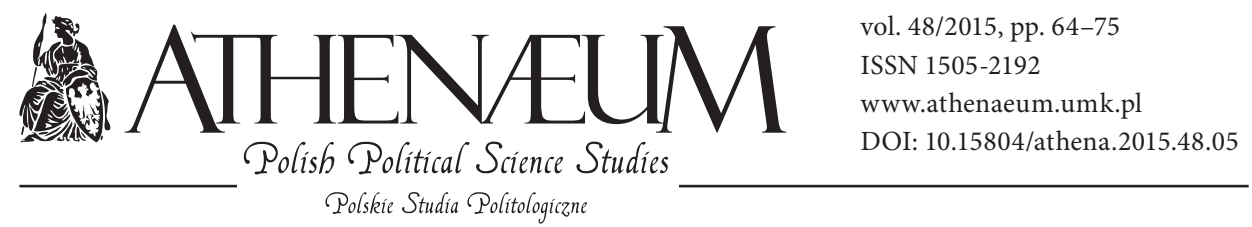

\title{
THE SYMBOLISM OF POPULISM
}

\author{
Andrei Taranu*
}

\begin{abstract}
The vast majority of the papers on populism describe this political phenomenon as one which is very difficult to explain and to analyze due to its discursive versatility and behavioural chameleonism. Furthermore, I would argue that the term populism covers more political and social realities than one single term would normally concentrate from a semantic point of view. I focus more over the psychological roots of populism which can be observed in the political symbolic field. In that manner, I consider that political symbolic, as part of the behavioural theory, can be a better tool for unveiling the populist discourse than the usual techniques of political analysis.
\end{abstract}

\section{- KEYWORDS -}

democracy, populism, behavioural theory

Politics is, as shown by Lucien Sfez, a business of symbols, because it is based on legitimacy (Sfez 2000). And legitimacy is an abstract reality that can be demonstrated only by political majority and the support of public policy rather than by specific or economic interests. For this reason, the struggle for legitimacy is probably more likely to take place in the realm of image and discourse than in the area of public policy. That is, politics - almost everywhere in the Western world and in other places as well - has become dependent of the electoral campaigns that slowly take over the whole public space, not only during elections (whatever they are) but also before and after the election. Basically the political space has

\footnotetext{
* National School of Political Sciences and Public Administration in Bucharest, Romania.
} 
become one of constant electoral campaigns, that is to say a sandbox where image and symbol take more space than political action itself, which aims mostly to take steps and innovate through public policy or through channeling public support for large projects, such as sending people to Mars or eradicating hunger from the planet.

This permanent campaign generated, as Guy Hermet points out, the emergence and strengthening of a new string of political parties, namely the populist parties (Hermet 2007). These parties are, as shown by the last decade and a half, not able to govern, but are able to mobilize societies and to gather enough votes to represent a real threat to main-stream political parties. And when we say they are not able to govern, we can give examples: Pym Fortuyn in the Netherlands, or the FPO in Austria, who came to power (in Austria they even gave the prime minister), did not produce any notable things in government, and were forced to retreat relatively quickly. But even in these conditions, populist parties continue to attract a wide electorate that is sufficiently large so as to control or at least influence most government. Take the case of Holland, where the Christian Democrat Conservative government was forced to enter an alliance with the Freedom and Justice Party of Geert Wilders, or Austria, where parties following contradictory ideologies (socialists and conservatives) were forced to ally themselves in order to isolate the populists, who were the kingmakers in the election. Thus, there was a certain political instability which led to early elections and that, in turn, led to a new electoral campaign.

The vast majority of works about political populism describe this phenomenon as being very difficult to explain and analyze due to its versatility in discourse and chameleonic behavior. In addition, I would add that the term "populism" describes many political and social realities, maybe more than one single term can concentrate semantically. Therefore, many analysts of the phenomenon like Guy Hermet (2007) or Gianfranco Pasquino (2008) try to introduce the term "populisms" instead of "populism", in their search to find a clear definition as to how this phenomenon could be defined. Some authors (Frölich-Steffen et al. 2005: 4; Mudde 2004: 541; Touraine 2007: 38) defined populism as a system of "post-industrial" parties leading to the sense of "post-classical". Others (Decker 2006; Knight 1998; Viguera 1993) defined it as a specific style of doing politics, that has a different discourse for each society, but that shares an intimate structure of behaviour and ideas.

Therefore, before assuming one definition, we should consider describing the main political elements that are regarded as populist, no matter the region where 
it is encountered: 1 . despise and even hate towards the elites; 2 . a strong anticorruption rhetoric; 3 . anti-system discourse based on the appeal to the people as a whole; 4. cultural (or religious) conservatism; 5. economic egalitarianism; 6 . rhetorical anti-capitalism; 7. assumed nationalism; 8. xenophobic behaviour and speeches; 9. contradictory public policies (when in government); 10. a foreign policy and an alliance system that is also anti-system (Krastev 2009).

Of course these are all pieces of a puzzle, and they are not found everywhere in the same formula, or with the same intensity at the same time. But each of these elements can be considered as expression of populism. And perhaps this is why the term "populisms" seems more correct than "populism" as a generic term.

Despite the rather large differences in behaviour and speech, there is a defining core that allows to take into account the multiple forms that can be embodied by populism. Canovan (1999) defines this common core as "a call to the people to unite against the established power structures and dominant ideas and values of society". The other definition belongs to Cas Mudde (2005), who tries to get a synthesis of populist discourse and he defines populism as an ideology with a diluted core that aims to devise society into two homogenous and antagonistic groups: the "pure people" against the "corrupt elites", arguing that policy should be the expression of the general will of the people. In a populist democracy nothing is more important than the general will, not even constitutional laws.

Increasing scientific interest about this subject reflects a growing presence of the populist discourse in the empirical reality of the global political landscape. This is also because it is happening in areas that appear to have nothing in common, and in the most unexpected forms. And yet the identity elements of populism seem to unite different social and political areas. We can generally distinguish three types of populism and they are largely considered to be quite different: the Latin American, the West European, and the Eastern and Central European discourse. We will try to show how the discourses and the political actions for the latter two are linked, which shows in turn that political discourse is becoming more and more globalized.

In Western Europe, the success of radical right populist parties like the National Front in France, or the Freedom Party in Austria, which have a stable base around $10 \%$ starting from the 80 s, has intrigued researchers. They built theories and analyzed this phenomenon, but their theories were not suited to describing populist parties in Central and Eastern Europe. This does not mean that essentially CEE parties had very different discourses, but that they were 
adapted to the political and social realities of their region. Parties like the Social Labour Party and the Greater Romania Party in Romania, Vladimir Mečiar's People's Party in Slovakia and others had both a nationalist and xenophobic discourse, dividing society between the "right people" and the "corrupt elites" like in the West, but they are related to different situations and to different targets.

Radical right-wing populist parties have had relatively comparable scores on both sides of the former Iron Curtain in Europe in the early 90s. Despite this common trait, most authors tend to focus their analysis on Western populism, avoiding the perspective of pan- European populism and a thorough examination of populism in post-communist countries. What little literature exists attempting at comparative studies on populism in this regard is deeply divided, as some authors focus on the intrinsic difference between populism in CEE and Western Europe, while others emphasize the risk of drawing artificial distinctions between the East and the West and generating different categories and realities, arguing that the phenomenon is pan-European. This latter group believes that the growing success of populist discourse in both parts of the EU is generated essentially by a common dissatisfaction of Europeans with democracy.

If we focus on the definition of populism pointed out earlier, these two approaches are not necessarily contradictory. In other words, there is a "common analytical core" (Panizza 2005), or a structure that can be found in populist discourse in both the East and the West. However, because populism appears on two fundamentally different political backgrounds: the well-established democracies of Western democracies and the post-communist East, we do need to analyze these different strings on both sides of the former Iron Curtain.

Before analyzing the various expressions of populism in Europe, it is necessary to define more precisely the "common analytical core" that Francisco Panizza (2005) uses to draw together these various forms of populism. Under his approach, populism is a speech against the status quo, which simplifies the political space, symbolically dividing society between "the People" and "the Others". "The People", under this perspective, is not an abstraction that is necessary for any democratic theory, but a unitary and homogeneous body, defined by its opposition to its enemies. The latter consists primarily of the political and economical elites that usurped political power, and of minorities that threaten the identity and homogeneity of "the People".

A defining characteristic of populist discourse is what Paul Taggart calls "the intrinsic chameleonic quality of populism" (Taggart 2000), which varies accord- 
ing to the specific realities in which the discourse takes place. In other words, there are always "signifiers devoid of content", which can take a variety of forms. According to Canovan (1999), the power structure of the state (or region) is essential in the formation of a specific populist discourse as populism is above all a reaction to the power of elites and the dominant political discourse. Therefore, by following this trail, we see a much better opportunity to identify specific forms of populist discourse in CEE and in Western Europe.

Depending on the definition of "the Other", we can find differences between populist discourse in the East and the West: for instance, while in Western populist rhetoric "the Other" is described as an external threat, an invasive structure threatening the homogeneity of the people, a category in which immigrants and those who are calling for economic or political asylum are included, "the Other" in CEE populist rhetoric is often an insider that has been a part of society for a long time, but that is not part of the nation as such, e.g. ethnic populations like Roma, Jews, and Hungarians (for Romania and Slovakia, for example). More precisely, in Eastern Europe populist discourse tends to be more inclined towards exclusion, having open racist and xenophobic overtones. As Cas Mudde (Mudde 2005) pointed out, anti-Semitism and racism are more widespread and accepted in CEE societies and, as a result, they are a more obvious part of radical political discourse while "populist political parties and even main stream parties [...] are less willing to act against racist or nationalist extremism than in the West" (Mudde 2005: page?). On the other hand, the argument for exclusion of radical right parties in Western Europe is based on economic speech ("immigrants steal our jobs") or sociological one ("they refuse to integrate"), becoming a form of political correctness of xenophobia.

While Western Europe has a long tradition of anti-establishment populist discourse, the elite being defining for those holding political power - and as Vilfredo Pareto's theory points out - the economical power as well, CEE antielites discourse is often associated with national-communism. In most cases, anti-elitism in Central Europe is often directed against the main party of the left political spectrum, especially the one considered the successor of the former communist party. The Polish case of the Order and Justice party of the Kaczynski brothers is extremely relevant, because it came to power with a profoundly anticommunist discourse a decade and a half after the collapse of communism in Central and Eastern Europe. Another fundamental difference between populisms of the Western post-communist countries is that, generally speaking, perhaps with the exception of Forza Italia (currently Popolo della Liberta) in Italy, politi- 
cal parties in Western Europe usually recognize the political legitimacy of its political enemies, or, in other words, take into account political pluralism as a necessary component of a functioning democracy. Chantal Mouffe takes the view that "the opposition monopoly against the established order" (Mouffe 2005) of populist parties in the West gives them the aura of adolescent rebels against the democratic order, allowing at the same time for them to be largely ignored as such. And they too are forced to respect the democratic order, which (they claim) is at the center of their ideology. Precisely because they hold so much to the people's will, they are unable to afford to question democracy, although they would like to impose their principles upon it. As Michael Shafir (2011) points out, "the image that non-populist politicians are trying to cultivate is one of the reluctant politician, whose entry into politics is considered a necessary evil which also demands his sacrifice. It follows then, that politicians who are non-populists are systemic at least in appearance. [...] they no longer aim for targets that would destroy the existing political system, but on the contrary, claim that their objective is to maintain a genuine democracy".

This is not necessarily the case of post-communist Europe, where center-right parties tend to have a similar populist discourse like their extremist nationalist counterparts, such as Fidesz and Jobbik in Hungary, or PDL and PRM in Romania. In their discourse, "left" part of the people is their main political opponent, and it is often regarded as an illegitimate representative of the nation, because it is associated, at least symbolically, with communism. Viktor Orban, leader of the ruling Fidesz party in Hungary, is a good example for this trend. After losing the 2002 elections in Hungary, he stated: "We, who are gathered here today, we are not and never will be in opposition. The Nation cannot be in opposition" (Tamas 2009). Even though it is officially a center-right party, Fidesz will adopt more and more populist perspectives, using the concept of nation in an extensive, even totalitarian sense, where representative democracy - the legitimacy of each elected person - is abandoned. Also, because of the banalization of the link between populism and nationalism in CEE, the center-right parties cannot distance themselves from and never truly have condemned the populist radical right, and are more open to forming coalitions with them (see again the Hungarian case, also Slovakia in 2012).

According to Panizza (2005), populism thrives in "times of crisis and distrust" as a result of the "failure of existing social and political institutions to limit and regulate political themes in a relatively stable order" (page?). In other words, populism is the most seductive ideology (or alternative) when the institutional 
system is unable to resolve the imbalances caused by general change or a specific crisis in the political, economic, or social spheres. This happens also because the number of unsatisfied demands and expectations grow in times of crisis and populist parties provide an explanation for the emergence of problems in the figure of "the Other" and an apparent solution which is to truly restore popular sovereignty.

In this sense, populism also offers to fulfill a vital function of representation, to "narrow the gap between representative and represented" (Panizza 2005), at times when traditional parties fail to do so. Populism is, therefore, not only an effective demand for change in the economic or social, but also a fever that reveals a "democratic malaise" (Mény, Surel 2002).

Most CEE states have adopted a multi-party democratic system somewhat abruptly after a long period of following the one-party model or a military dictatorship (for Poland), which led, in fact, to the reproduction of the one-party model to competing political parties, each being more interested in the political game than in building policy that is adapted to their societies. Moreover, by routinely adopting European programs to better integrate in the EU, these parties have "forgotten" how to make programmatic politics and been interested only in accessing power. Their societies then seem to be taken "hostage" by populist discourse, the only one which is directly addressed to them. Hence, the democratic malaise appeared once mainstream parties could no longer perform a service for the community, but only to support the interest groups around them.

In this analytical framework, the rise of populism in Western and in postcommunist societies can be linked, at least partially, to accelerated social and economic change that people had to face in the last 30 years. All the EU, new and old, had to cope with an increasing pressure generated by the opening of the economies to international competition, Europeanization, the transition to a post-industrial economy, and an aging population. Not only have these changes generated high social costs, but they also meant that severe constraints were put on the ability of the state to address these costs, which led to a considerable reduction in welfare. In this context, populist parties were able to build their discourse on discontent caused by these changes by targeting the "losers" of globalization in the West and the "losers" of transition in post-communist countries. But populist discourse did not propose solutions to the economic crises, it only tried to find guilt in the "profiteering political elites" (Mudde 2007). In general, especially in CEE, populist parties are adepts of an ultraliberal economic model, 
similar to the American one, and some western populist parties have the same economic principles as well.

Of course, economic differences between the East and the West continue to be extremely important, even though both face similar social and economic situations due to the economic crisis. But the political changes are more different. Populism appears in Western Europe in a time of redefinition of discrepancies between party systems operating within the democratic well-known landmarks. On the other hand, populism appears in CEE at a time in which democracy and political identification are in the process of being invented. This difference can be defined by using the concept of inheritance: while most Western European political systems are based on a legacy that is fundamentally democratic, in CEE countries the system is based on an authoritarian legacy, often called "communist" or "national communist". Through the concept of inheritance, beyond the specific elements, we can also speak of a "crisis of representation" in both parts of Europe.

Populism in Western Europe was often viewed as a side effect of the depoliticization of public action and the increased importance of consensual politics in contemporary democracies. According to Mouffe (2005), Western populism stems from the predetermination of liberal values over democratic ones, and from an end of adversative politics in Western democracies. The crisis of representation is the key here, because those who disagree with the establishment's main parties consensus feel that they have lost the ability to influence representatives according to their wishes. Citizens feel that politicians have a different agenda, driven by political correctness and multiculturalism, while their own problems lie elsewhere. In this sense, populism is a symptom of a dysfunctional democracy: it occurs because the principle of popular sovereignty has been neglected, and that, in the words of Canovan (1999), is a principle that is "reaffirmed as a populist challenge".

On the other hand, depoliticizing political action can not explain the specifics of populism - especially since there is no such depoliticization - in CEE, in particular, its mass character and its drive for the exclusion of "undesirables". Firstly, politics in the new EU Member States can hardly be described as consensual. Although there was a covert consensus, at least concerning foreign affairs and economic policy in the 1990s, most CEE party-systems have rapidly become extremely and adversatively polarized around socio-cultural values. The cleavage communist/anti-communist stayed the main driver of Eastern European policy for a long time but was expanded to include the element of minority exclusion. 
For example, in Poland, when the Kaczynski brothers were holding power, communists, Jews, and gays have played roughly the same role of "enemies" of the people.

Sigmund Freud shows that the identification process is a psychological process that is fundamental for forming the self (ego), but that this process is rather social than personal, because it takes place as a process of assimilation of external models and it takes place during the whole lifetime (but especially in the first part) through a series of processes of comparison and assimilation of identities (Freud 2010). The process described by Freud is complicated and we will not discuss it here, but what is important is that there are three types of identification: 1. primary identification (between personal self and the given self, where given - that is the name provided by society), 2. narcissistic identification (of the young man) and 3. partial (secondary) identification: with a leader or a social or cultural model. This third identification interests us most, because it belongs - according to Freud - to the adults, to people with a conscience, who are being seduced by models whom they tend to copy. It is a projection of the group upon its leader and a projection of its leader upon his loyal subjects. And in a society that has passed through decades of moral infantilization (as shown by Pascal Bruckner) and the assumption of the star system model, the middle class individual has a much greater appetite for identification with his hero, which can be a real leader or just an ideal type.

In this process of identification both group affiliation and group trust are forged, which gives comfort, solidarity, and finally an identity (geographically, affiliation, emotional attachment, etc.). But at the same time, the relation to "the Other" is formed, the one who is not part of the group and does not share the same identity and who is often not willing (or is not wanted) to integrate. Thus, the alien (as in the sense of otherness to the group, not necessarily in the ethnic sense) turns into the enemy, into the one who is not like us. This identification process is best explained by Umberto Eco: "Having an enemy is important not only to define our identity, but also to procure an obstacle, to measure ourselves and our value-system against it, and to show by confronting it, our own value. Therefore, when there is no enemy, one has to be constructed" (Eco 2011). Of course, this is an experience that the vast majority of human individuals go through during their social and psychological formation. But Pascal Bruckner gives us a very interesting hint, namely that in recent decades more and more adults in the West refuse to assume the social responsibilities incumbent to modernity and because they have to, in order to do so, deny reality in a certain 
sense, it leaves them increasingly attracted to the negative discourse of populism (Bruckner 2005).

Two social phenomena overlap: on the one hand, we are witnessing an everincreasing impoverishment of the middle class and at the same time, a growing infantilization of this social group (still the widest in contemporary society), both compared to the previous generations, who were socially more active and economically optimistic. Both these processes, apparently contradictory, are not to be understood on a personal level, but one can see that there are longer and longer periods of unemployment, there is a deprivation and a lack of average welfare, a lack of an economic and political project, and they all tend to generate sympathy for populist discourse.

Populism starts, as most ideologies do, by referring to myths and political symbols, especially negative ones. The major symbol is the Alien/Enemy that can take many forms, depending on the adopted cultural and historical model: it may mean the Muslim, the Roma (Gypsy), the Polish, or the Corrupt, the Rich, the Poor (the one who does not want to work) etc. By relating to the Alien /Enemy, populist currents on the left and the right pay the price of a democratic election being transformed into a battle between a majority of the people against a minority that is branded as the cause for which the majority cannot retain its true original identity. All populist currents are nationalistic, no matter what doctrine they claim to follow, thus nationalism and Euroscepticism become the emblems of contemporary European populism.

It must be said that nationalism as a political principle is not the same in Western and in Central and Eastern Europe. R. Griffin (2003) is the one who coined the term "ethnocratic liberalism" to describe this paradoxical form of European populism, that enthusiastically embraces a liberal system of political and economic competition, but considers at the same time that only some members of an ethnic group as being full members of society. The nationalism assumed by the National Front in France, the Northern League, the Flemish Block and others involve a rejection of the ideas of multiculturalism, proposing some kind of nostalgia for a mythical world of racial and cultural homogeneity. In other words, right-wing European populism brings into question a nationalism that is centered on an ethnic community and tradition, and is often the advocate of xenophobia and authoritarianism in regards to immigration and free movement of persons. For example, the Flemish Block proclaims its sympathy for the former apartheid system in South Africa claiming the "Eerste eigen volk" (our people must come first), leading to a complete separation of Belgium: 
Flanders for the Flemish, Wallonia for the Walloons (Francophone), Europe for European whites. And the Flemish model is not unique, as similar principles were promoted by Haider in Austria and by Bossi in Italy during the last decade. We see that this kind of populist reaction is not just against the ruling elite but also against all those who are in one way or another considered foreigners.

The most obvious elements of this form of populism is anti-immigrationism, and in principle, it is considered the most important. But anti-immigration must not be understood as having only an economic basis, reducing the successformula of populist fear mongering only to the loss of workplaces or higher taxes in order to pay social allowances for the poor of other countries. This issue does occupy a specific place in populist discourse, but the essence of this discourse is rather cultural and political than economical. The fear that populism tries to provoke is similar to that of Oswald Spengler at the end of the First World War: the fall of European culture under the domination of the far East, only the actors have changed.

In contrast, Central and Eastern nationalism is more complex, being both endogenous and exogenous: it reacts both to internal factors (national, ethnic, or religious minorities) and to external factors (especially to the "Russian threat"). From this perspective, nationalism had (and still has in some countries) a positive connotation especially in societies that have lived for over four decades in a "dissolution of the nation-state into an internationalist socialist order" (Minkenberg 2002). Therefore, appeal to historicism and national memory is constantly a part of post-communist populist discourse. What is interesting is that most CEE societies still value European integration, but continue to appeal to specific national characteristics and religious cultural differences. Populistnationalist leaders in Romania like Corneliu Vadim Tudor and László Tőkés worked together in the European Parliament (declaring their belief in European values) and simultaneously build ultranationalist identity discourses related to a philosophy of ethnic separation.

By becoming a source of symbols and myths, contemporary European populism is undergoing a fast transformation into a real doctrine (even if it features many national flavors) and it does so by first challenging the mainstream ideologies of the last century and offering an alternative to them. 


\section{REFERECES:}

Birnbaum P. (2012). Genèse du populisme. Le peuple et les gros. Plurier: Grasset.

Bruckner P. (2005). Tentatia Inocentei. Bucuresti: Ed. Nemira.

Canovan M. (1999). Trust the People! Populism and the Two Faces of Democracy. "Political Studies" 47 (1).

Dix R.H. (1985). Populism: Authoritarian and Democratic. "Latin America Research Review"Vol. 20, Issue 2.

Eco U. (2011). Cum ne Construim Dusmanul. Polirom: Iasi.

Freud S. (2010). Psihologia Inconstientului. Opere Esentiale. Vol 3. Bucuresti: Ed. Trei.

Griffin R. (1997). Interregnum or Endgame? Radical Right Thought in "Post-fascist Era". "Journal of Political Ideologies" 2.

Hermet G. (1997). Populisme et nationalisme. "Vingtième Siècle. Revue d'histoire" 56. Paris: Sciences Po University Press.

Hermet G. (2007). L'hiver de la democratie. Paris: Armand Colin.

Laclau E. (2000). De l'importance des signifiants vides en politique. La guerre des identités, Grammaire de l'émancipation, Paris: La DecouverteMAUSS.

Mény Y., Surel Y. (2002). The Constitutive Ambiguity of Populism. [in:] Democracies and the Populist Challenge. Y. Mény, Y. Surel (eds.). Basingstoke: Palgrave.

Miklos T.G. (2009). Despre Stanga Eterena. Revista 22. Bucuresti.

Minkenberg M. (2002). The Radical Right in Postsocialist Central and Eastern Europe: Comparative Observations and Interpretations. "East European Politics and Societies" 16.

Mouffe Ch. (2005). The "End of Politics" and the Challenge of Right-Wing Populism. [in:] Populism and the Mirror of Democracy. F. Panizza (ed.). London: Verso.

Mudde C. (2002). In the Name of the Peasantry, the Proletarian, and the People: Populism in Eastern Europe. [in:] Democracies and the Populist Challenge. Y. Mény, Y. Surel (eds.). Basingstoke: Palgrave.

Mudde C. (2005). Racist Extremism in Central and Eastern Europe. "East European Politics and Societies" 19 (2).

Mudde C. (2007). Populist Radical Right Parties in Europe. Cambridge: CUP.

Panizza F. (2005). Introduction, Populism and the Mirror of Democracy. [in:] Populism and the Mirror of Democracy. F. Panizza (ed.). London: Verso.

Pasquino G. (2008). Populism and Democracy. [in:] Twenty-first Century Populism. The Spectre of Western European Democracy. D. Albertazzi, D. McDonnell (eds.). Palgrave: Macmillan.

Sfez L. (2000). Simbolistica Politica, Iasil: Ed. Institutului European. 